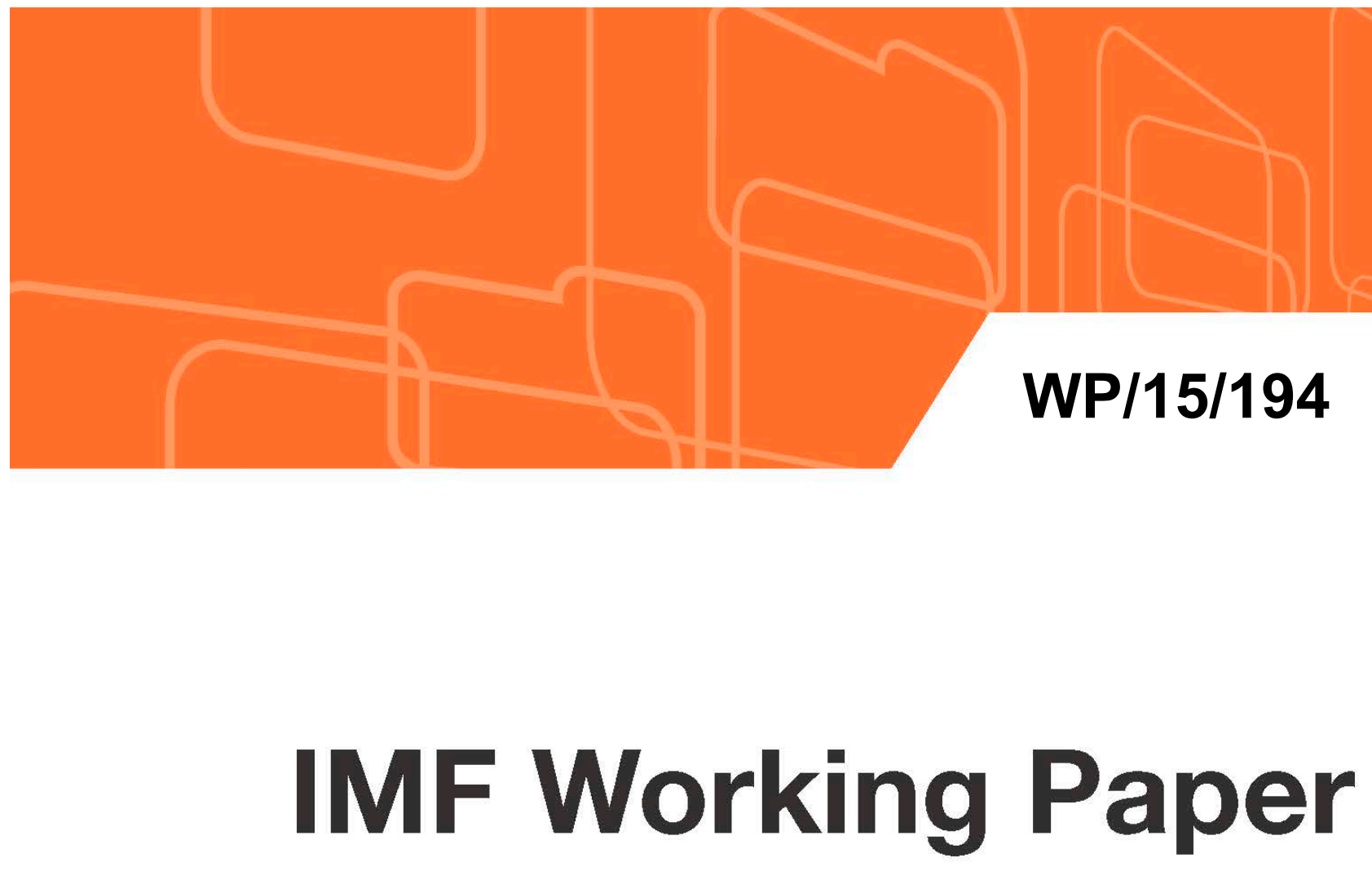

\title{
Normalization of Global Financial Conditions: The Implications for Brazil
}

\author{
by Troy Matheson
}

IMF Working Papers describe research in progress by the author(s) and are published to elicit comments and to encourage debate. The views expressed in IMF Working Papers are those of the author(s) and do not necessarily represent the views of the IMF, its Executive Board, or IMF management.
I $\mathbf{N}$
N T E R
R N A T I O N A L
M O N E T A R Y
F U N D 


\title{
IMF Working Paper
}

Western Hemisphere Department

\section{Normalization of Global Financial Conditions: The Implications for Brazil Prepared by Troy Matheson}

Authorized for distribution by Alfredo Cuevas

June 2015

IMF Working Papers describe research in progress by the author(s) and are published to elicit comments and to encourage debate. The views expressed in IMF Working Papers are those of the author(s) and do not necessarily represent the views of the IMF, its Executive Board, or IMF management.

\begin{abstract}
Global financial conditions are poised to tighten further as the global recovery proceeds. While monetary policy normalization should be a healthy global development as growth continues to recover in advanced economies, financial spillovers seen during the taper episode - which started with the announcement in May 2013 of possible tapering of U.S. asset purchases - hint at potential challenges for Brazil. The Fed's communications related to normalization have improved significantly since the taper episode and, at present, a rise in Fed Funds rate in 2015 is widely anticipated by markets - arguably the most widely anticipated tightening of monetary policy in history. While Brazil could benefit from tighter global financial conditions associated with improved global prospects, bouts of heightened uncertainty about the future course of monetary policy cannot be ruled out. Thus, the correct diagnosis of the underlying reasons behind tighter global financial conditions remains crucially important for Brazil. Adverse spillovers can be mitigated by strengthening policy frameworks and fundamentals.
\end{abstract}

JEL Classification Numbers: C10, C50, E40

Keywords: Interest rates, Economic news, Vector-autoregression

Author's E-Mail Address: tmatheson@,imf.org 


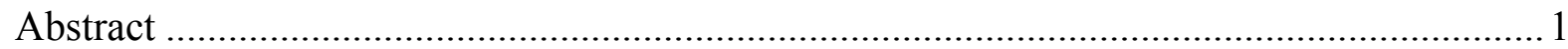

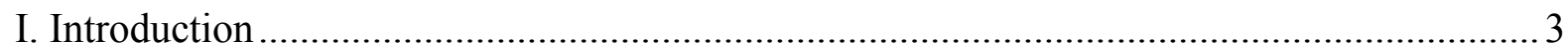

II. Why did Long-Rates Rise in the U.S.? ........................................................... 3

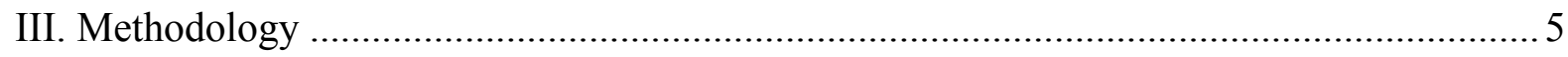

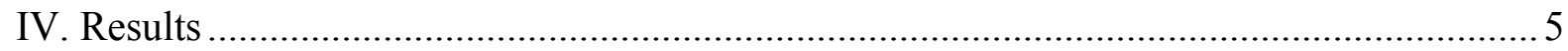

V. Why are Brazilian Interest Rates so Responsive to U.S. Developments? ....................... 8

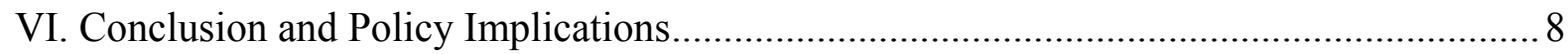

Figures

1. Brazil and U.S. Sovereign Bond Yields ................................................................. 3

2. Cumulated Change in U.S. 10Y Bond Yield................................................................... 4

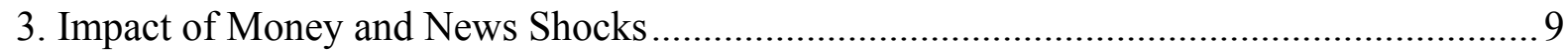

4. Impact of Brazilian Long Rate: Baseline and Weekly Model......................................... 10

5. Explanatory Power of Different Shocks at Different Horizons......................................... 11

6. Cumulated Changes Since Taper Episode and Contributions .......................................... 12

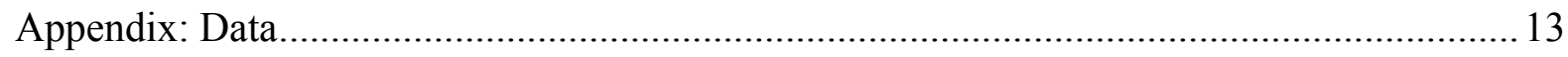

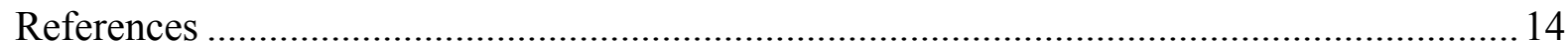




\section{INTRODUCTION}

The May 2013 announcement of possible tapering of U.S. Federal Reserve asset purchases revealed potential challenges going forward. In response to a question during his testimony to Congress on May 22, 2013, Ben Bernanke said that whenever stimulus efforts began to taper off, it would not happen in an "automatic, mechanistic program" and that "any change would depend on the incoming data." After the details of the Federal Open Market Committee meeting on April 30 and May 1, 2013 were released later that day, many market participants were surprised by the number of voices inside the Fed calling for a slowdown in the stimulus effort in the near future. The announcement triggered significant volatility amid a re-pricing of risk and capital flow reversals in some emerging markets, including Brazil. In the U.S., 10-year Treasury bond yields rose by about 100 basis points during the summer. By the end of August, Brazilian 10-year Government bond yields had risen by more than 200 basis points and the real had depreciated by around 15 percent against the U.S. dollar. (The central bank had started a monetary tightening cycle in April to curtail inflation concerns; as part of this cycle, the central bank raised its benchmark interest rate by 150 basis points between the taper speech and end-August.)

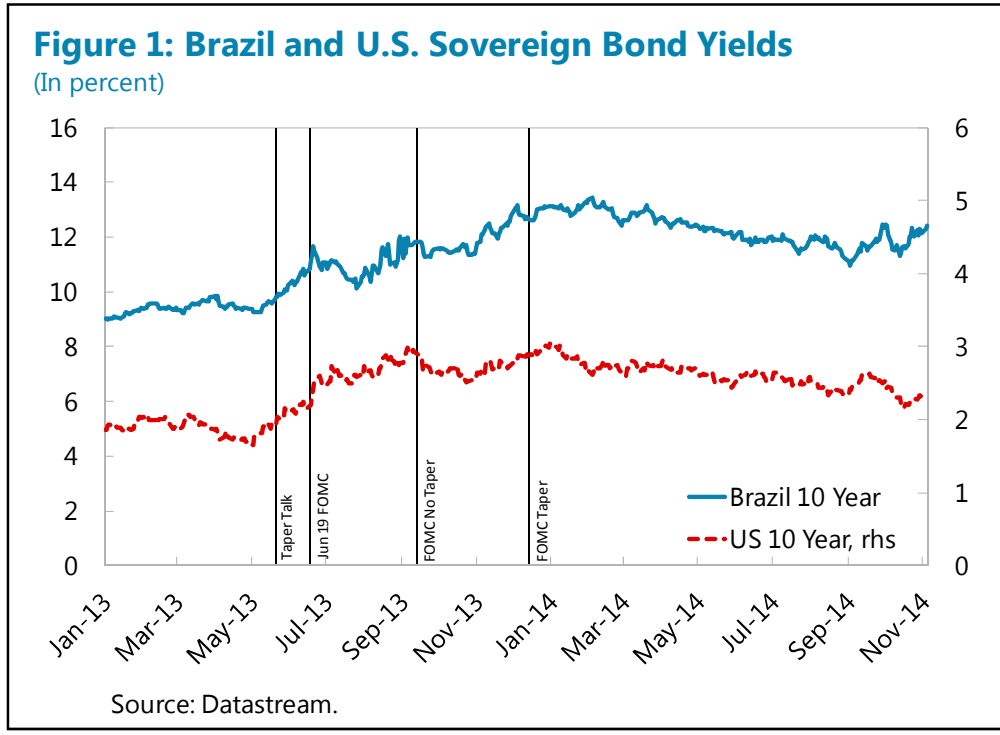

A key lesson from the taper episode is that the source of tightening of financial conditions is critical to understanding transmission channels and spillovers. Monetary policy normalization due to better economic prospects in advanced economies should be a healthy global development. However, the adjustment in global financial conditions triggered by the tapering announcement was followed by unusual volatility in financial markets. As noted in IMF (2014), tightening monetary conditions due to better economic prospects has not historically been coupled with such uncertainty and re-pricing of risk. This highlights the importance of differentiating between shocks to financial conditions from economic developments - growth or risk appetite — and shocks from monetary developments.

\section{WHY DID LONG-RATES RISE IN THE U.S.?}

The rise in the long-term Treasury yield can be attributed to monetary shocks (related to uncertainty about the future course of monetary policy) and shocks related to better economic prospects. As discussed in IMF (2014) and Matheson and Stavrev (2014), the approach used to distinguish between these two shocks relies on a sign-restricted VAR 
estimated at the daily frequency. The intuition is simple: positive (tightening) money shocks push up yields and depress stock prices; positive economic news shocks increase both yields and stock prices.

\section{Monetary policy shocks drove up long-term bond yields in the U.S. immediately after the} tapering announcement, but shocks related to better economic prospects have since become increasingly important (Figure 2). Uncertainty about the future course of monetary policy, "monetary shocks", dominated in the immediate aftermath of the tapering announcement, adding about 20 bps to the U.S. 10-year bond yield in May 2013 and another 30 basis points following the FOMC meeting in June 2013, where the Federal Reserve confirmed that tapering could begin by the end of 2013. The FOMC meeting in September revealed that tapering would not begin before the end of 2013, with the press release noting that the Committee saw the improvement in economic activity and labor market conditions since it began its asset purchase program as consistent with the growing underlying strength in the broader economy. Nevertheless, just prior to that announcement, monetary shocks had already accounted for

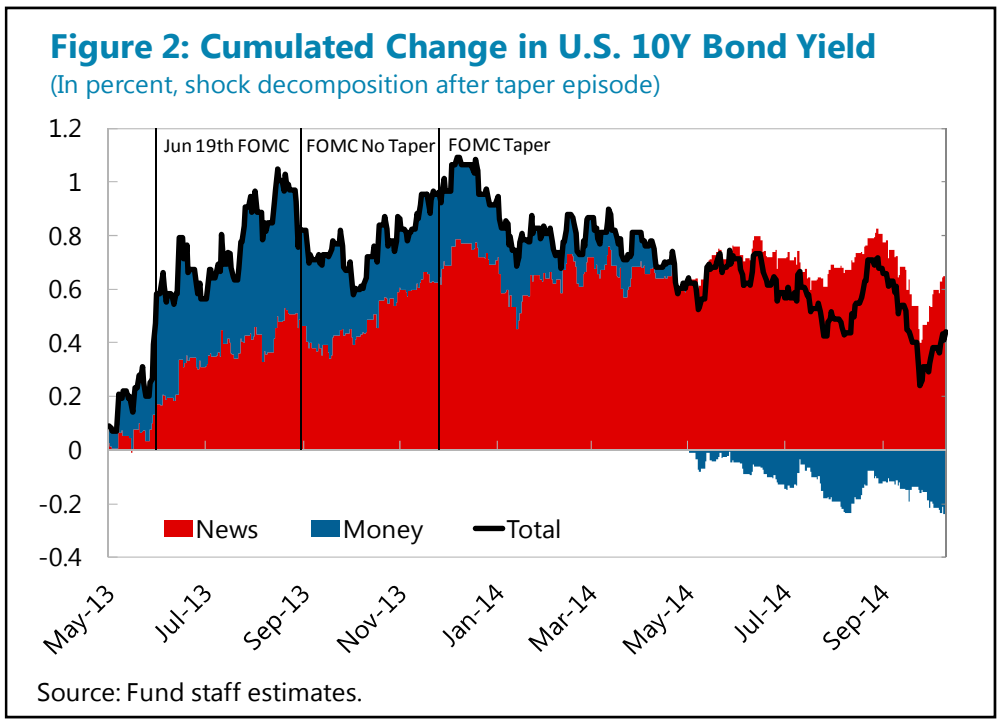
the majority of the 100 basis points rise in 10-year yields since May 2013. The subsequent announcement in December (in which tapering was confirmed to begin in 2014) had little impact on yields, and was perceived by markets as confirmation of the Fed's desire to taper due to an improving economic outlook.

Federal Reserve communications have improved since the taper episode, reducing the impact of monetary shocks on long rates. Janet Yellen was confirmed as the new Chairperson of the Federal Reserve Bank Board in early 2014, and the Fed has gradually improved its communications related to monetary policy normalization. In particular, the end of asset purchases in October 2014 was widely anticipated by markets due to the sucessful Fed communications throughout the year. The eventual rise in the Fed Funds rate from the zero lower bound has also been well commuicated to markets, with expectations that the rise will occur in ernest during 2015. At the same time, the Fed's communications under Janet Yellen have increasingly been perceived as being more 'dovish' than under Ben Bernanke, putting downward pressure on long rates since the middle of 2014. 


\section{What was the Impact on Brazil?}

As global economic prospects improve, financial conditions will continue to normalize and tighten going forward. However, as the tapering episode in 2013 showed, the communication and interpretation of monetary policy intentions in the U.S. could also pose policy challenges for Brazil. To better understand how global developments impact the Brazilian economy, we employ an empirical approach that utilizes the U.S. monetary and economic news shocks described above.

\section{Methodology}

This exercise treats developments in the U.S. as being exogenous to developments in Brazil. By estimating the historical shock contributions to 10-year bond yields for the U.S. from monetary and economic news shocks and treating them as exogenous to developments in Brazil, we can disentangle the differentiated effects of these two shocks on the Brazilian economy using a simple vector-autoregressive (VAR) model. The VAR is estimated using monthly data from late 2006 and includes the following domestic variables: the central bank's real economic activity index, the policy interest rate, the 10-year government bond yield, the CPI, the nominal exchange rate versus the U.S. dollar, and business confidence. ${ }^{1}$ It is assumed that U.S. developments can affect Brazilian variables contemporaneously (within a month) and through lags, but Brazilian variables cannot affect the U.S. variables. Note that the sample period is limited because Brazil only began issuing 10-year government bonds in late 2006.

\section{RESUlts}

What are the implications of a 100 basis point increase in 10-year bond yields in the U.S. for Brazil? The results when the 10-year bond yield increases by 100 basis points due to either a monetary shock or a news shock in the U.S. are displayed in Figure 3. The bars reflect average responses of the domestic variables over a 6 month period when the model is simulated 1000 times; the lines reflect the standard deviation of the average responses. Note that the size of each shock is relatively large when put in context - that is, a shock that raises the 10-year bond yield in the U.S. by 100 basis points would typically imply a significantly larger increase in the Fed funds rate. Note also that, given the small sample size, the confidence bands around the estimates are relatively wide. ${ }^{2}$

While higher interest rates in the U.S. increase interest rates in Brazil, the impact on the rest of the Brazilian economy depends on the nature of the shock. Regardless of the nature

\footnotetext{
${ }^{1}$ The natural logarithm is taken of each variable prior to estimation, except interest rates, which are left as levels (see the appendix for a more detailed description of the data). The model includes one lag of all variables, as suggested by the Schwarz-Bayesian criterion.

${ }^{2}$ Overall, the impacts on the Brazilian variables are qualitatively very similar to those found in IMF (2014) for emerging economies more generally.
} 
of the shock in the U.S., the policy rate and the long rate (10-year bond yield) rise by a quantitatively significant amount. Monetary shocks increase the policy rate by around 80 basis points and the long-rate by around 200 basis points, effectively steepening the yield curve. In contrast, positive economic news prompts an increase in the policy rate and the long rate of around 100 basis points, leaving the slope of the yield curve broadly unchanged. The relatively large impacts on the policy rate and the long rate suggest the central bank has responded to foreign developments relatively strongly since 2006 .

The impact on Brazilian long-rates is broadly in line with other studies and alternative specifications. As discussed above, this work aims to examine how the effects of a change in the U.S. 10-year bond yield resulting from better economic news differs from a change resulting from monetary shocks. In contrast, most other studies focus on the impact of changes in U.S. yields, without determining why the changes occur. This makes the results difficult to compare. Nevertheless, averaging the impacts of economic news and monetary policy shocks give us a rough basis for comparison. The results show that a 100bps rise in the U.S. 10-year bond yield that is equally driven by economic news and monetary shocks leads to a rise in Brazil's 10-year bond yield by around $150 \mathrm{bps}$. This impact is broadly similar to results found using different estimation methodologies, sample periods, and data frequencies (see, for example, Kamil and others, 2014, and IMF, 2013). Likewise, a smaller model including only the U.S. shocks and the Brazilian long rate and estimated at the weekly frequency yields similar results to the baseline specification (see Figure 4).

The implications for the domestic variables differ depending on the nature of the shock. In particular, the results suggest:

- A monetary shock depreciates the exchange rate, and reduces economic activity and business confidence. A monetary shock in the U.S. leads to a depreciation of the Brazilian real's nominal exchange rate against the U.S. dollar as U.S. assets become more attractive to investors. At the same time, worsening prospects for the U.S. economy and higher domestic interest rates reduce business confidence and economic activity.

- A positive economic news shock appreciates the exchange rate, increases activity and business confidence, and puts upward pressure on prices. Better economic prospects in the U.S. improve the outlook for global demand and Brazil's nominal exchange rate appreciates against the U.S. dollar. Economic activity and business confidence improve in Brazil, increasing the price level.

Developments in the U.S. have a significant impact on interest rates in Brazil, particularly at longer horizons (Figure 5, top 2 panels). The results show that a significant proportion of the forecast error variance of the Brazilian policy rate is driven by domestic developments at 
short horizons. ${ }^{3}$ However, developments in the U.S., particularly shocks related to economic news, account for more than $3 / 4$ of the variance of the policy rate after one year. In contrast, the forecast error variance of the long rate is impacted almost immediately by monetary shocks in the U.S., with positive economic news becoming increasingly important over time.

Domestic developments are more important drivers of the exchange rate, output, the price level, and business confidence (Figure 5, bottom 4 panels). Unlike interest rates, domestic shocks are more important drivers of the forecast error variance for the other Brazilian variables. This suggests that financial linkages between the U.S. and Brazil are much tighter than linkages through economic activity and trade. Interestingly, the nominal exchange rate against the U.S. dollar is also more driven by domestic factors than by developments in the U.S. This likely reflects links between domestic fundamentals and a risk premium associated with investing in Brazil. This result, however, should be treated with an element of caution, because here we assume that structural shocks to the exchange rate are domestically sourced, while in practice they will capture all developments not explained by the other variable in the model (some of which may be foreign).

What happened after the taper episode in May 2013? Figure 6 shows contributions to the cumulated changes in the domestic variables since April 2013. The results suggest:

- Positive economic developments in the U.S. appear to have significantly contributed to the rise in interest rates. Monetary shocks had an important positive impact on long-term yields immediately following the taper episode, but this effect began to unwind by the end of summer 2013. Positive economic news in the U.S. then became the most important driver of the long-term rate, with domestic developments (possibly associated with perceptions about country risk) also becoming more important over late 2013 and early 2014.

- The exchange rate depreciated because the impact of positive U.S. economic news was outweighed by U.S. monetary shocks and negative domestic developments. The exchange rate initially depreciated sharply following the taper episode, but it recovered some ground following the central bank's announcement of the FX intervention program in August.

- Activity, prices, and confidence benefited from better U.S. economic news, but this was largely offset by the impact of deteriorating domestic conditions. The deterioration in domestic conditions was quite dramatic. From mid-2013 to mid-

\footnotetext{
${ }^{3}$ The decomposition shows the amount of information each shock contributes to explaining each variable in the VAR by determining how much of the forecast error variance of each of the variables can be explained by each of the exogenous shocks. Forecasts for each variable in the model at each point in time are uncertain due to developments in the (structural) shocks. Given the estimated parameters of the model, including the estimated shock variances, the forecast error variance for each variable can be computed at each horizon, allowing each forecast error variance to be attributed among the different structural shocks.
} 
2014, consensus growth forecasts for 2014 fell by around 1.5 percent to just over 1 percent and inflation expectations rose by around 0.5 percent, close to the ceiling of the tolerance region around the target.

\section{WhY ARE BRAZILIAN INTEREST RATES SO RESPONSIVE TO U.S. DEVELOPMENTS?}

Fundamentals matter. IMF (2014) suggests that key fundamentals can dampen the response to money shocks. In particular, emerging economies with relatively strong fundamentals experienced lesser reactions to rising long-term yields in the U.S. Higher reserves, lower inflation, a higher current account balance, deeper financial markets, and stronger underlying growth all help mitigate adverse spillovers from tighter global financial conditions. Thus, the evidence suggests that deteriorating domestic fundamentals have contributed to the heightened responsiveness of Brazilian yields relative to other emerging economies.

\section{Conclusion ANd Policy IMPlications}

As economic prospects in the U.S. continue to improve, financial conditions are expected to normalize in a smooth fashion. Overall, recovery in the U.S. is beneficial to the global economy and Brazil. However, the tapering episode highlighted that potential challenges may arise going forward.

Central banks' objectives have become more complex, giving rise to communication challenges, and the potential for further bouts of market volatility. Following the global financial crisis, central banks have become more mindful of the tradeoff between financial stability and price stability. This potential conflict in objectives is amplified by the need to manage the multiple instruments (policy rates and balance sheets), adding to the complexity of policy communication going forward, and raising the specter of further bouts of uncertainty and market volatility.

The appropriate policy responses will depend on the underlying drivers of tighter financial conditions. The results suggest that positive global economic developments will put upward pressure on interest rates, and cause nominal exchange rate appreciation and output gains, while money shocks will trigger nominal exchange rate depreciation and output losses. Getting the correct diagnosis of tighter global financial conditions is thus critical to choosing the best policy course.

Sound policy frameworks and fundamentals can mitigate spillovers. Better understanding the role of policy credibility and sound fundamentals in the transmission of global shocks will improve economic policy, especially monetary policy. Spillovers from money shocks have typically been milder in countries with sound policy frameworks and fundamentals. Spillovers could also be amplified if a lack of credibility hinders the ability to respond to global shocks. 
Figure 3: Impact of Money and News Shocks

(average over six months, shocks increase US10 year bond yield by $100 \mathrm{bps}$ )
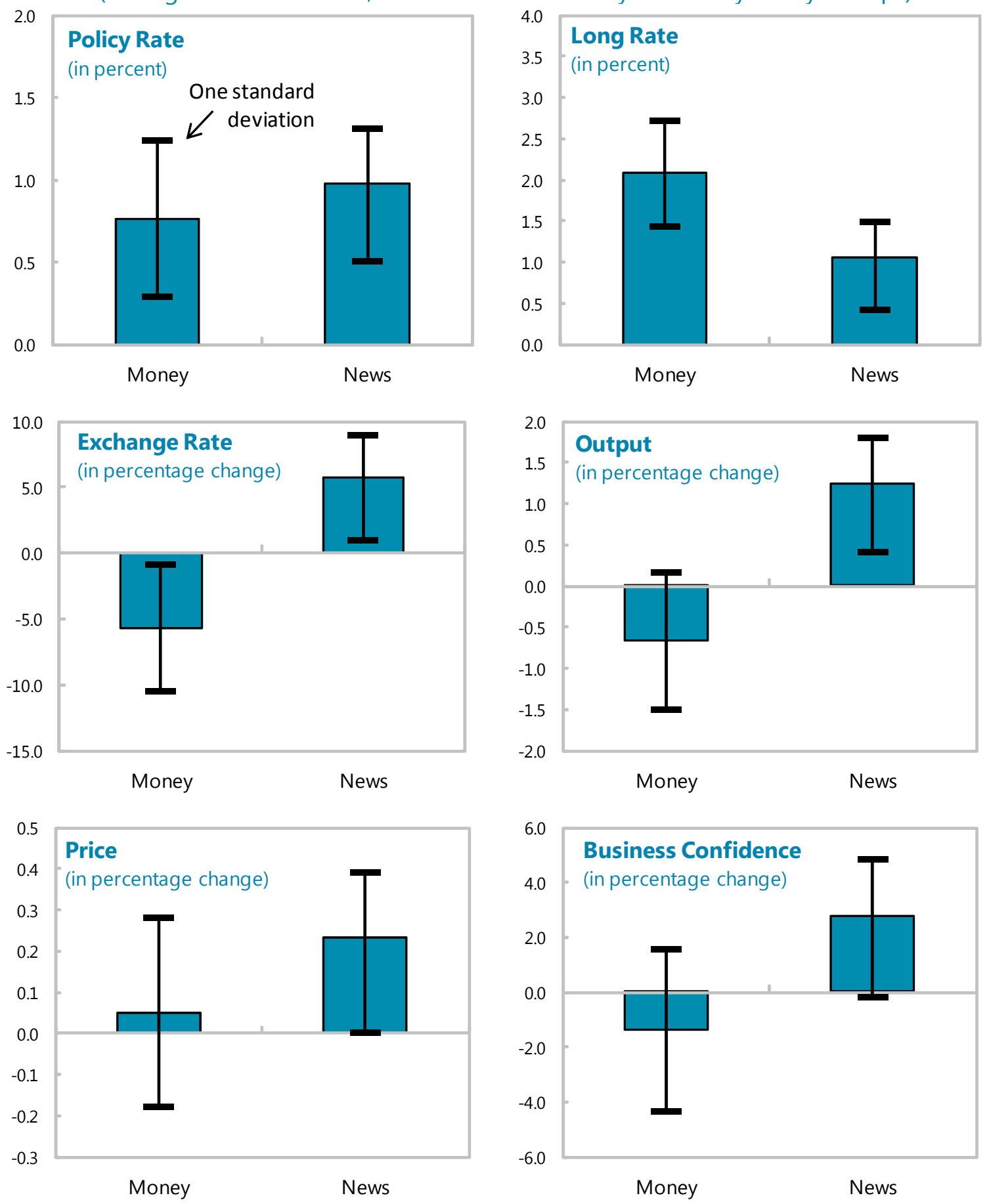

Source: Staff estimates. 
Figure 4. Impact on Brazilian Long Rate: Baseline and Weekly Model (Average over six months, shocks increase U.S. 10 year bond yield by $100 \mathrm{bps}$ )
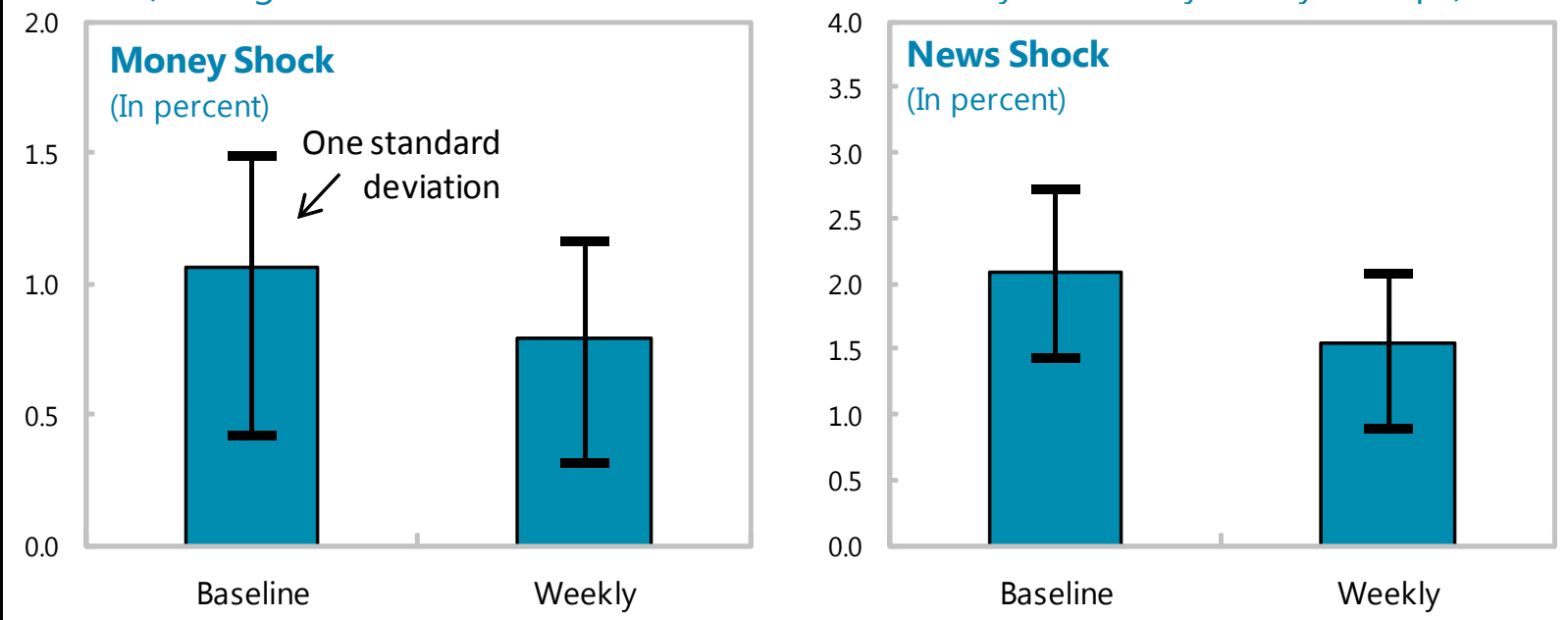

Source: Fund staff estimates. 


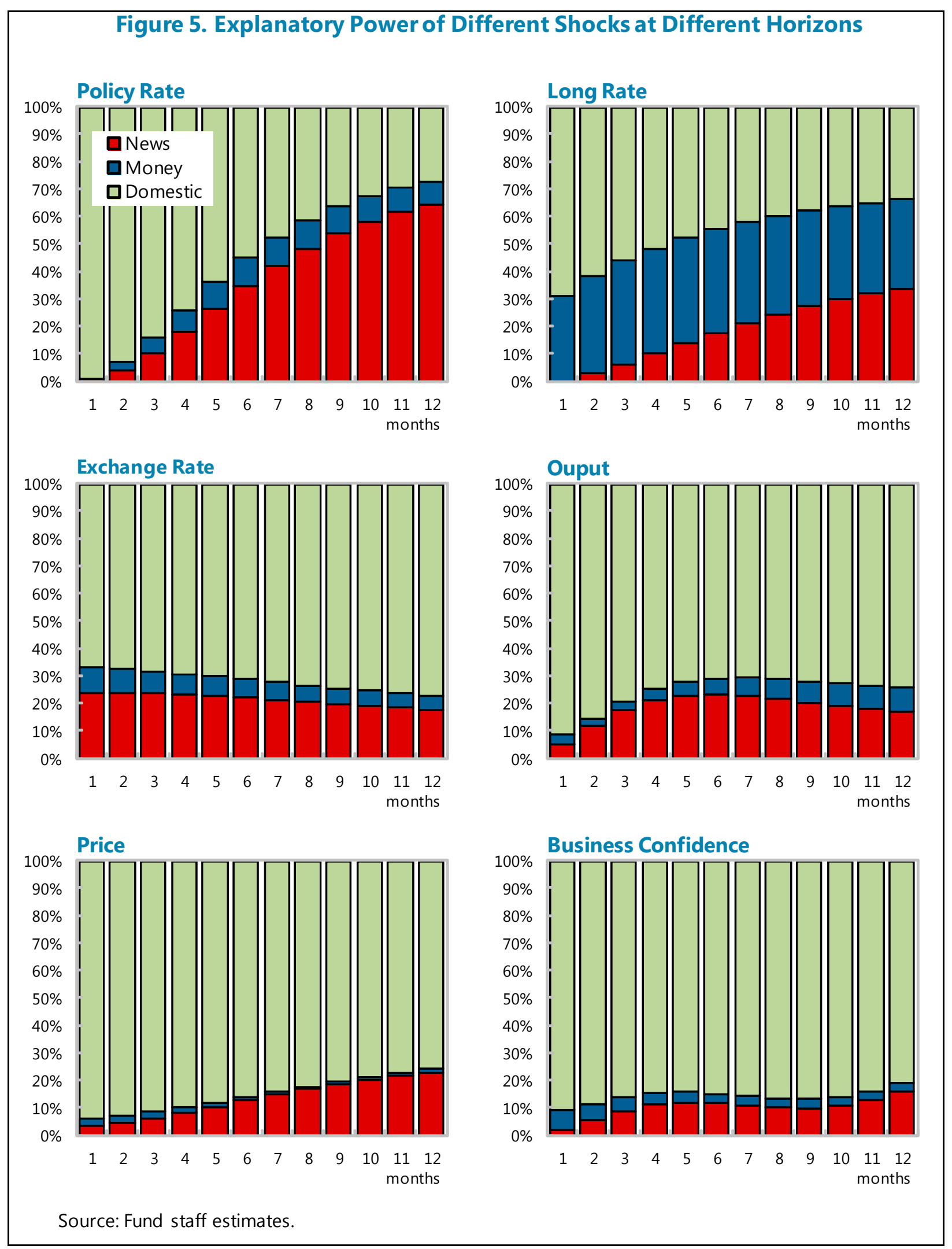


Figure 6. Brazil: Cumulated Changes since Taper Episode and Contributions
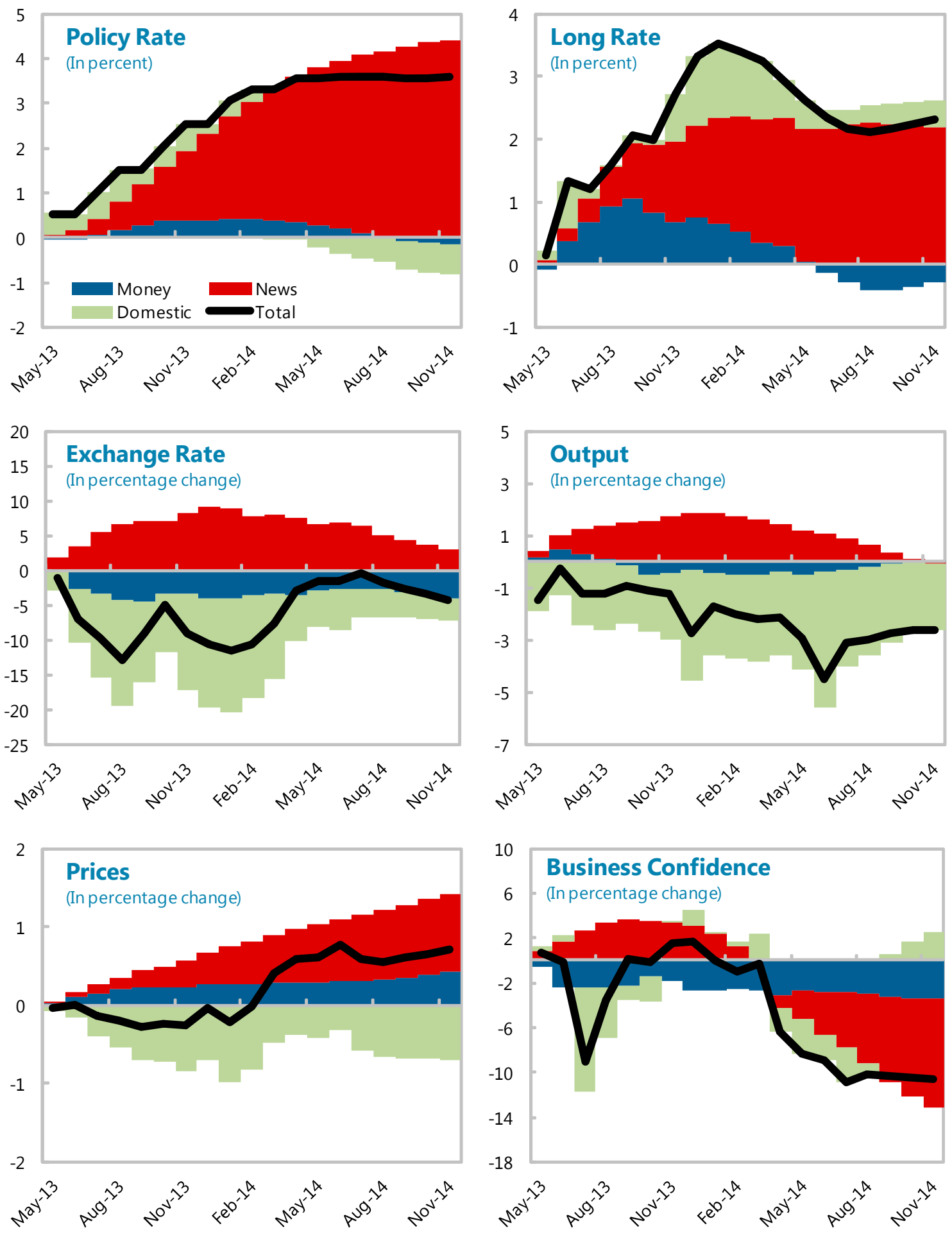

Source: Fund staff estimates. 


\section{Appendix: Data}

The data used in the empirical work are described below.

\section{United States (Daily Data)}

10-year Treasury Yield at Constant Maturity (Board of Governors of the Federal Reserve System)

S\&P 500 Index (The New York Times)

\section{Brazil (Monthly Data)}

SELIC Target Interest Rate (Banco Central do Brasil)

10-year Government Bond Yield (Haver)

Nominal Exchange Rate, reias/dollar (Banco Central do Brasil)

Economic Activity Indicator, seasonally adjusted (Banco Central do Brasil)

Extended National CPI, seasonally adjusted (Instituto Brasileiro de Geografia e Estatística)

Business Confidence Index, seasonally adjusted (Confederaçâo Nacional da Indústria) 


\section{REFERENCES}

International Monetary Fund, 2013, "Global Financial Stability Report," Available via the intranet at https://www.imf.org/External/Pubs/FT/GFSR/2013/02/index.htm

Kamil, Herman, Carlos Góes, Phil de Imus, Mercedes Garcia-Escribano, Roberto Perrelli, Shaun K. Roache, and Jeremy Zook, 2015, “The Effect of U.S. Monetary Normalization on Emerging Markets' Sovereign Bond Yields: The Different Cases of Brazil and Mexico," IMF Working Paper, forthcoming.

Matheson, Troy, and Emil Stavrev, 2014, "News and Monetary Shocks at a High Frequency: A Simple Approach,” Economics Letters, Volume 125 Issue 2, pp. 282-86.

International Monetary Fund, 2014, “Spillover Report,” IMF Multilateral Policy Issues Report, pp. 27-57. Available via the Intranet at

http://www.imf.org/external/np/pp/eng/2014/062514.pdf 